\title{
I Szczecińska Konferencja Romanistyczna pt. „Civis Romanus sum. Mistrzowie i dzieła polskiej romanistyki" Szczecin 18-20 września 2015 r.
}

W dniach 18 - 20 września 2015 r. odbyła się I Szczecińska Konferencja Romanistyczna pt. "Civis Romanus sum. Mistrzowie i dzieła polskiej romanistyki”. Miejscem obrad konferencji, zorganizowanej przez Katedrę Prawa Rzymskiego, Historii Prawa i Doktryn Polityczno-Prawnych Uniwersytetu Szczecińskiego, był usytuowany w sąsiedztwie Puszczy Bukowej i jeziora Szmaragdowego, hotel Panorama w Szczecinie. Naukowe spotkanie romanistów honorowym patronatem objął Prezydent Miasta Szczecina.

Celem konferencji było przybliżenie postaci i spuścizny naukowej polskich uczonych zajmujących się prawem starożytnego Rzymu.

Pierwszą sesję, której przewodniczyli prof. dr hab. Maria Zabłocka (Uniwersytet Warszawski) i prof. dr hab. Marek Kuryłowicz (Uniwersytet Marii Curie-Skłodowskiej), otworzyło wystąpienie dr Elżbiety Loski (Uniwersytet Kardynała Stefana Wyszyńskiego), Civis Romanus sum. Aktorskie skazy na honorze obywatela. Kolejne referaty wygłosili: dr Piotr Sadowski (Uniwersytet Opolski), Wkład księdza profesora Michała Wyszyńskiego w rozwój polskiej romanistyki; dr hab. Maciej Jońca (Katolicki Uniwersytet Lubelski Jana Pawła II), Prawo rzymskie w lesie. Uwagi na temat dydaktycznej działalności Borysa Łapickiego w latach okupacji hitlerowskiej; dr Łukasz Marzec (Uniwersytet Jagielloński), Stanisław Wróblewski a krakowska szkoła romanistyczna; dr Renata Kamińska (Uniwersytet Kardynała Stefana Wyszyńskiego), Marceli Chlamtacz - lwowski cywilista i romanista okresu międzywojennego.

Nad przebiegiem obrad drugiej sesji czuwali prof. dr hab. Jan Zabłocki (Uniwersytet Kardynała Stefana Wyszyńskiego) i prof. dr hab. Andrzej Sokala (Uniwersytet Mikołaja Kopernika). Referaty wygłoszone w jej trakcie dotyczyły następujących zagadnień: dr Ireneusz Jakubowski (Uniwersytet Łódzki), Proff. J. Kodrębski i C. Kunderewicz - polscy romaniści II poł. XX w.; dr Tomasz Palmirski (Uniwersytet Jagielloński), Krakowska szkoła romanistyczna po 1945 r.; dr Bożena Czech-Jezierska (Katolicki Uniwersytet Lubelski Jana Pawła II), Profesorowie prawa rzymskiego wobec "reformy Baszkiewicza"; prof. dr hab. Witold Wołodkiewicz (Uniwersytet Humanistycznospołeczny Szkoła Wyższa Psychologii Społecznej w Warszawie), Romanistyka warszawska II i III Rzeczypospolitej.

Drugi dzień obrad rozpoczęło wystąpienie przygotowane wspólnie przez prof. dr hab. Marka Kuryłowicza i dr hab. Renatę Świrgoń-Skok (prof. 
Uniwersytetu Rzeszowskiego), Systematyka polskich podręczników prawa rzymskiego. Następnie głos zabierali: dr Krzysztof Szczygielski (Uniwersytet w Białymstoku); Adolf Berger (1882-1962). Życiorys naukowy oraz dr Łukasz Korporowicz (Uniwersytet Łódzki), Jan Kanty Rzesiński - zapomniany romanista polski. Prowadzenie tej części konferencji organizatorzy powierzyli prof. dr hab. Witoldowi Wołodkiewiczowi i dr hab. Annie Tarwackiej (Uniwersytet Kardynała Stefana Wyszyńskiego).

Prelekcje wygłoszone podczas ostatniej sesji, której przewodniczyli dr hab. Zuzanna Benincasa (Uniwersytet Warszawski) i prof. dr hab. Krzysztof Amielańczyk (Uniwersytet Marii Curie-Skłodowskiej), koncentrowały się wokół takich kwestii, jak: dr hab. Marzena Dyjakowska (prof. Katolickiego Uniwersytetu Lubelskiego Jana Pawła II), Henryk Insadowski - profesor prawa rzymskiego w Katolickim Uniwersytecie Lubelskim; prof. dr hab. Piotr Niczyporuk (Uniwersytet w Białymstoku), Romaniści Akademii Wileńskiej; dr Przemysław Kubiak (Uniwersytet Łódzki), Kilka uwag Romulada Hubego na temat ope et concilio; dr hab. Jerzy Krzynówek (prof. Uniwersytetu Warmińsko-Mazurskiego), Konstrukcja posiadania w ujęciu Stanisława Wróblewskiego.

Prezentowane wystąpienia spotkały się z dużym zainteresowaniem uczestników, czego dowodem była żywa dyskusja toczona po zakończeniu poszczególnych sesji. Podkreślić należy, iż dzięki staraniom organizatorów uczestnicy konferencji mogli obejrzeć wspaniałe dzieła sztuki znajdujące się w Pergamonmuseum i Altes Museum w Berlinie.

Krzysztof Szczygielski 